Journal of Engineering and Applied Sciences 15 (7): 1703-1708, 2020

ISSN: 1816-949X

(C) Medwell Journals, 2020

\title{
Effects of Air Bubble Injection on the Efficiency of a Flat Plate Solar Collector: An Experimental Study for the Open Flow System
}

\author{
Heba Qasim Mohammed, Ali Sh. Baqir and H.S. Khwayyir Hasan \\ Engineering Technical College of Najaf, Al-Furat Al-Awsat Technical University, \\ 31001 Al-Najaf, Iraq
}

\begin{abstract}
This study aims to study experimentally with and without the effects of small air bubble injection on the efficiency of a flat plate solar collector with tube rises for open flow system. The variation of the thermal efficiency of the solar flat plate collector due to both different of the water flow rate and due to the air bubbles injection with air flow rates are evaluated. A new experimental procedure for injecting small air bubbles into the riser tubes of solar flat plate collector is proposed. The comparison between the effects of forced water flow rates and air bubbles injection on the solar flat plate thermal efficiencies with a variation of solar radiation intensity were investigated. Water and air flow rate were changed between 1.5-2.5 LPM with inlet water temperature ranged between $19-23.5^{\circ} \mathrm{C}$. Observations showed that the injecting of air bubbles inside the solar flat plate tubes risers play key roles on the effect of thermal efficiency more than that of using the water flow rate without air bubbles injection. Small air bubbles injecting into the risers tubes of the flat solar collector causes enhancement of the thermal efficiency and it increased 3.5-5.25\% depending on air flow rate.
\end{abstract}

Key words: Solar flat plate collector with tubes risers, micro or small air bubbles injection, different water flow rate, thermal efficiency, temperature

\section{INTRODUCTION}

The use of solar energy has become a necessity in the current century because of the power plants produce large pollution in the ground and ambient environment. Also, the cost of electricity consumption from power plants weighs heavily on the user, especially, at peak time. One of the most important problems related to the large consumption of electric power is domestic electric heaters. Domestic hot water production plants using solar radiation are considered low thermal efficiency and need much academic research to improve their thermal performance. At present many researchers have used new technologies that are environmentally friendly and have low operating capacity and low price to improve the thermal parameters of heat exchangers (Baqir, 2010; Baqir et al., 2016; Mahood et al., 2018; 2019).

Matuska et al. (2009) build and described a solar thermal flat collector with a user-friendly interface program to determine solar collector efficiency and thermal parameters. Ji et al. (2011) evaluated to modify the solar collector system for the heating period operation under the water heating mode with natural circulation flow. The show that the services hot water in the warm seasons without bringing in summer overheating problem. Solar flat plate collector with sandwich type was tested by Raj Thundil et al. they painted the solar collector by silica-based black paint. They improved the solar flat plate collector efficiency. Manjunath et al. (2012) enhancement the surface of solar flat plat collector by adding dimples to the collector surface. They improved a water temperature of about $5.5^{\circ} \mathrm{C}$ for a dimple solar collector as compared to that of a flat plate solar collector. Ceylan (2012) studied the energy analyses of the temperature controlled solar flat plate collector water heater. TCSWH was experimentally analyzed at $40-55^{\circ} \mathrm{C}$ and compared with the natural circulation system. Chong et al. (2012) proposed a fabricated V-trough solar water warm system using the forced circulation system. They improved the thermal efficiency with low cost. Sahoo et al. (2016) investigated experimentally several parameters such as solar tilt global radiation, hot water temperature, the flow rate of water distillation and the flow rate of hot brackish of water distillation. Ullah et al. (2017) concluded that when the ambient temperature is low, double glass cover heat preservation effect is more obvious and the instantaneous efficiency is highest.

The main scope of the present paper is to experimentally clarify the effect of air bubble injection with various air flow rates and forced water flow rate with spirit way on thermal characteristics of a solar flat plate collector. Air flow is injected inside the tube risers.

Theoretical calculation: Flat plate solar collectors are widely used for a water warming system in domestic applications and for space heating by solar power. The

Corresponding Author: Heba Qasim Mohammed, Engineering Technical College of Najaf, Al-Furat Al-Awsat Technical University, 31001 Al-Najaf, Iraq 


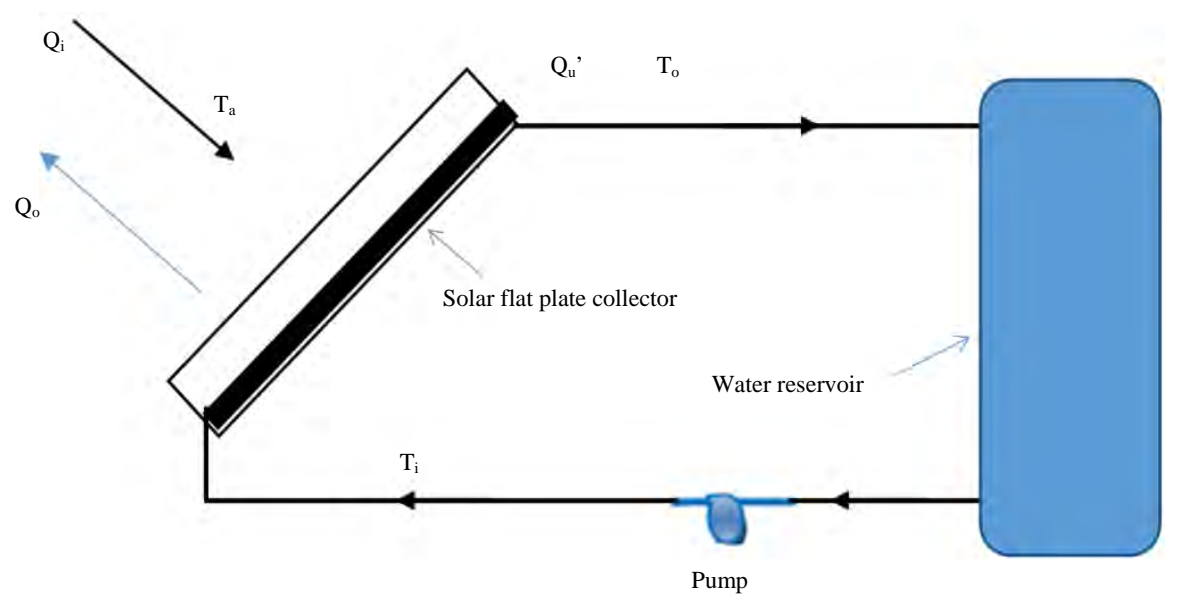

Fig. 1: Schematic diagram for a typical solar heating system

most common solar flat plate collector is insulated and vacuumed metal box with a glass cover and a dark coloured absorber tube rises which attached with the absorber plate surface. The solar flat plate collectors used to heat or warm liquid like water at a temperature more than $70^{\circ} \mathrm{C}$.

Figure 1 shows the schematic of a typical solar system with flat plate solar collector and a storage tank. If I is the intensity of solar radiation in $\mathrm{W} / \mathrm{m}^{2}$ incident on the surface area of $\mathrm{A}, \mathrm{m}^{2}$, then the amount of heat gained by flat plate collector or the useful heat gain can be expressed by the following equation (Tang et al., 2010; Bolaji, 2006):

$$
\mathrm{Q}_{\mathrm{u}}=\mathrm{F}_{\mathrm{R}} \mathrm{A}\left[\alpha \tau \mathrm{I}-\mathrm{U}_{\mathrm{o}}\left(\mathrm{T}_{\mathrm{i}}-\mathrm{T}_{\mathrm{a}}\right)\right]
$$

Where:

$\mathrm{F}_{\mathrm{R}}$ : The collector heat removal factor

$\mathrm{U}_{\mathrm{O}}$ : The overall heat loss for the collector $\left(\mathrm{W} / \mathrm{m}^{2}{ }^{\circ} \mathrm{C}\right)$

$\alpha$ : The absorption coefficient

$\tau$ : The transmission coefficient of glazing

$\mathrm{T}_{\mathrm{i}}$ : The solar collector inlet liquid temperature $\left({ }^{\circ} \mathrm{C}\right)$

$\mathrm{T}_{\mathrm{a}}$ : The ambient temperature $\left({ }^{\circ} \mathrm{C}\right)$

Equation 1 can be written as follows (Bolaji, 2006):

$$
\mathrm{Q}_{\mathrm{u}}=\dot{\mathrm{m}} \mathrm{C}_{\mathrm{p}}\left(\mathrm{T}_{\mathrm{o}}-\mathrm{T}_{\mathrm{i}}\right)=\mathrm{U}_{\mathrm{o}} \mathrm{A}_{\mathrm{o}}\left(\mathrm{T}_{\mathrm{s}}-\mathrm{T}_{\mathrm{b}}\right)
$$

and from the definition of thermal resistance, the total resistance can be written as:

$$
\frac{1}{\mathrm{U}_{\mathrm{o}} \mathrm{A}_{\mathrm{o}}}=\frac{1}{\mathrm{~h}_{\mathrm{i}} \mathrm{A}_{\mathrm{i}}}+\frac{\operatorname{In}\left(\frac{\mathrm{d}_{\mathrm{o}}}{\mathrm{d}_{\mathrm{i}}}\right)}{2 \pi \mathrm{K}_{\mathrm{t}} \mathrm{L}}
$$

Where:

$\dot{\mathrm{m}} \quad$ : The mass flow rate of water $(\mathrm{kg} / \mathrm{sec})$

$\mathrm{C}_{\mathrm{o}} \quad$ : Specific heat capacity of water $\left(\mathrm{kJ} / \mathrm{kg}{ }^{\circ} \mathrm{C}\right)$
$\mathrm{T}_{\mathrm{o}}$ : The solar collector outlet water temperature

$A_{0}$ : Outside the surface area of the riser tube $\left(\mathrm{m}^{2}\right)$

$\mathrm{T}_{\mathrm{s}}$ : The absorption surface temperature $\left({ }^{\circ} \mathrm{C}\right)$

$\mathrm{T}_{\mathrm{b}}$ : The bulk temperature $\left({ }^{\circ} \mathrm{C}\right)$

$h_{i} \quad$ : The inside tube riser water convection heat transfer coefficient $\left(\mathrm{W} / \mathrm{m}^{2}{ }^{\circ} \mathrm{C}\right)$

$\mathrm{A}_{\mathrm{i}} \quad$ : Inside surface area of the riser tube $\left(\mathrm{m}^{2}\right)$

$\mathrm{d}_{\mathrm{o}}, \mathrm{d}_{\mathrm{i}}$ : Outside and inside tube riser diameter, respectively

$\mathrm{K}_{\mathrm{t}} \quad$ : The conductivity of tube riser $\left(\mathrm{W} / \mathrm{m}^{\circ} \mathrm{C}\right)$

$\mathrm{L} \quad$ : The length of tube riser (m)

Bulk temperature can be written as follows:

$$
\mathrm{T}_{\mathrm{b}}=\frac{\left(\mathrm{T}_{\mathrm{o}}+\mathrm{T}_{\mathrm{i}}\right)}{2}
$$

The experimental friction factor in the present work is determined from the Darcy Weisbach equation (Taherian et al., 2011):

$$
\Delta \mathrm{p}=\mathrm{f} \frac{\mathrm{L}}{\mathrm{d}_{\mathrm{h}}} \frac{\rho_{\mathrm{w}} \mathrm{V}^{2}}{2}
$$

Where:

$\Delta \mathrm{p}:$ The pressure loss $\left(\mathrm{N} / \mathrm{m}^{2}\right)$

$\mathrm{f}$ : The Darcy friction factor

$\mathrm{d}_{\mathrm{h}}$ : The hydraulic diameter $(\mathrm{m})$

$\mathrm{V}$ : The water flow average velocity $(\mathrm{m} / \mathrm{sec})$

$\rho_{\mathrm{w}}$ : Water density at bulk temperature $\left(\mathrm{kg} / \mathrm{m}^{3}\right)$

The efficiency of solar flat plat collector $\eta_{\mathrm{c}}$ for heating systems is the relationship between useful heat gain and collector solar radiation incident $\mathrm{I}$ on the absorber of, so, the lar collector can be expressed as:

$$
\eta_{\mathrm{c}}=\frac{\mathrm{Q}_{\mathrm{u}}}{\mathrm{IA}}
$$



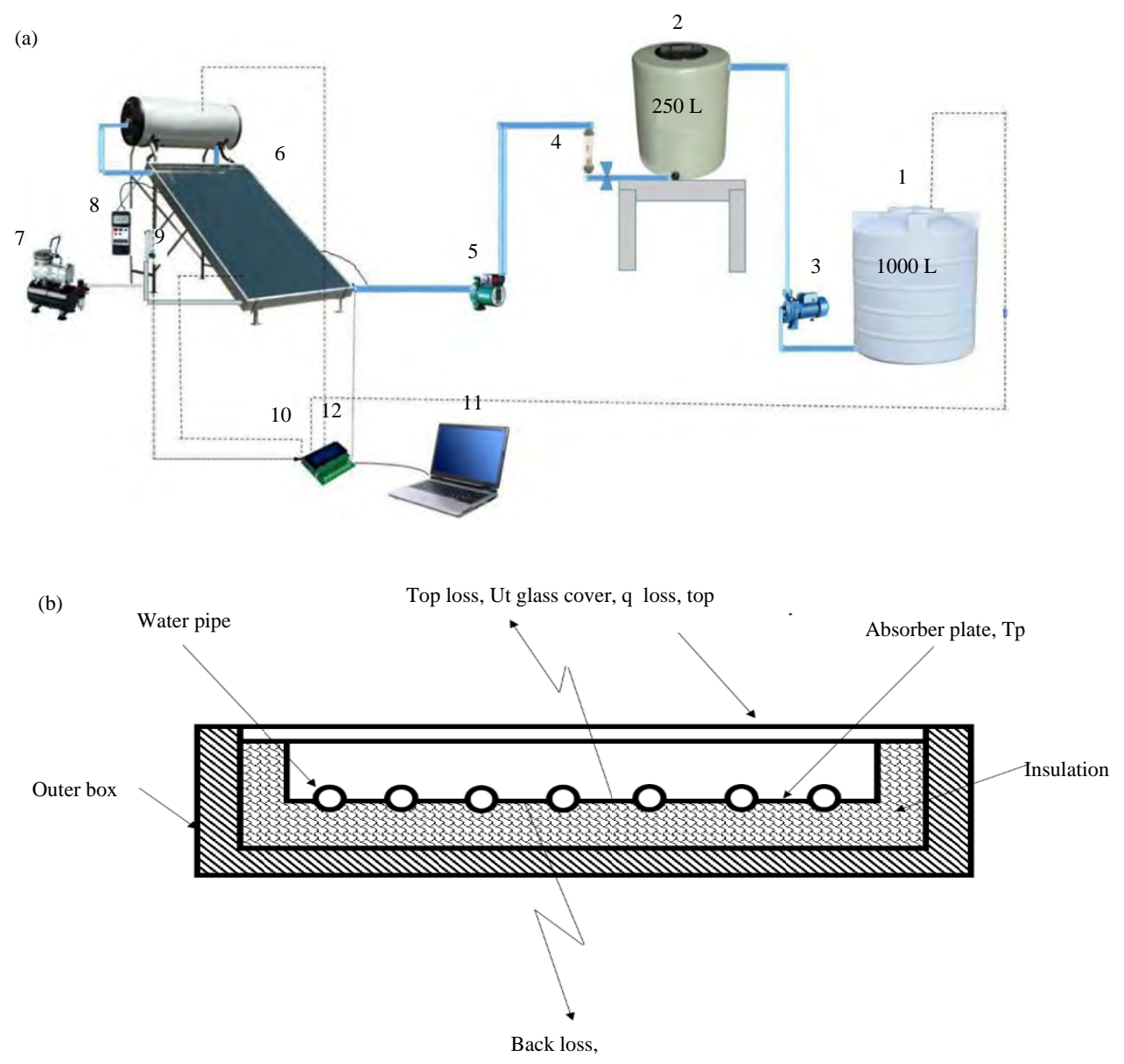

Fig. 2(a-b): (a) Schematic diagram of the experimental rig and (b) Schematic diagram of the flat plate solar collector with water pipes

\section{MATERIALS AND METHODS}

Experimental work: The temperature distribution along the riser tubes surface, inlet fluid, outlet fluid, ambient and the intensity of solar radiation were measured utilizing the experimental unit (Fig. 2a). The practical experiments of the solar system established in the Najaf city Iraq and the experimental rig consists of several components shown in the following Fig. 2a, b and Table 1 the solar collector dimensions are $2000 \times 1000 \times$ $80 \mathrm{~cm}$ length, width and thickness, respectively. The main component of the flat plate collector. Casing, glass cover, absorber plate, heads and tubes and insulation. The casing is made of aluminium alloy 6063-T5 black and absorber material are made of selective material with absorptance $\geq 95 \%$ and emittance $\leq 5 \%$ the welding method in the collector is laser welding of the absorber plate to the absorber pipe ensures a quite high mechanical connect resist the high-temperature gradients and thermal expansion. The two head tube in collector is made of
Table 1: Components of the work system

\begin{tabular}{ll}
\hline Variables & Components \\
\hline Tank & $1000(\mathrm{~L})$ \\
Tank & $250(\mathrm{~L})$ \\
Water pump & $10-20(\mathrm{~L} / \mathrm{min})$ \\
Flow meter & $0.5-4(\mathrm{~L} / \mathrm{min})$ \\
Small water pump & $0.5-4(\mathrm{~L} / \mathrm{min})$ \\
Flat plate collector & $1000-2000-80(\mathrm{~mm})$ \\
Compressor air & $150(\mathrm{~W})$ \\
Manometer digital & $5-2000(\mathrm{mbar})$ \\
Air flow meter & $1-5(\mathrm{~L} / \mathrm{min})$ \\
Data logger & 8 channels digital sensor temperature \\
PC & Saving data \\
\hline
\end{tabular}

copper with diameter $22 \mathrm{~mm}$ and thickness $0.6 \mathrm{~mm}$ and consists with 7 riser tube (Fig. 2b) made of branch tube with diameter $8 \mathrm{~mm}$ and thickness $0.6 \mathrm{~mm}$ branch tubes pitch $110 \mathrm{~mm}$ and the insulation material used in the collector is fiber class with thickness $30 \mathrm{~mm}$ the density of fiber glass $60 \mathrm{Kg} / \mathrm{m}^{3}$, the glass cover thickness $3.2 \mathrm{~mm}$ low iron tempered The solar collector system consists of several components and their purpose is to study the 
performance of solar collector by injecting micro air bubbles inside the collector and consists of tank $250 \mathrm{~L}$ mounted on the table with height $135 \mathrm{~cm}$ and another tank $1000 \mathrm{~L}$ connected to it to stabilize the temperature of water at the time of the experiment. About six experiments are conducted with three different flow, multi experiments for single phase and Multi experiments for two-phase flow. In the present study experiment air compressor $150 \mathrm{~W}$ used with the tube used to inject micro bubble inside the collector with diameter $8 \mathrm{~mm}$ and length $95 \mathrm{~cm}$ and contains very small holes and number 950 holes and data logger with 8 channel digital temperature sensor stabilizers on inlet and outlet of collector and one on the absorber and storage tank installed above the solar collector and another measuring the temperature of ambient the flow used in the test $1.5,2,2.5 \mathrm{~L} / \mathrm{min}$ is constant for single and for two-phase flow with water/micro air bubbles. All measurements in the present study were displayed directly by using the PC through the data logger and the steady-state results conditions were collected when the experiment reached steady state.

\section{RESULTS AND DISCUSSION}

The uncertainty of measurements was performed to estimate the error between the true value and experimental results are tabulated as in Table 2.

In the present work, two studies were used and compared with them. The first study is to find the efficiency of the solar heater system using a water pump to rotate the water through the solar heater and the second study is the same as the first study but without a water pump where the water is recycled through the solar heater using the effect of injecting small air bubbles under the solar heater and forming what is known as in the practical bubble pumping (slug flow).

In both studies, the mass flow rate was equal. In the first study, the mass flow of water ranged between (1.5-2.5) LPM. In the second study and with the bubble pumping, the mass flow rate of water was stabilized as in the first study.

Figure 3 referred to the first study and it's clearly shown that the variation of the solar flat plate efficiency

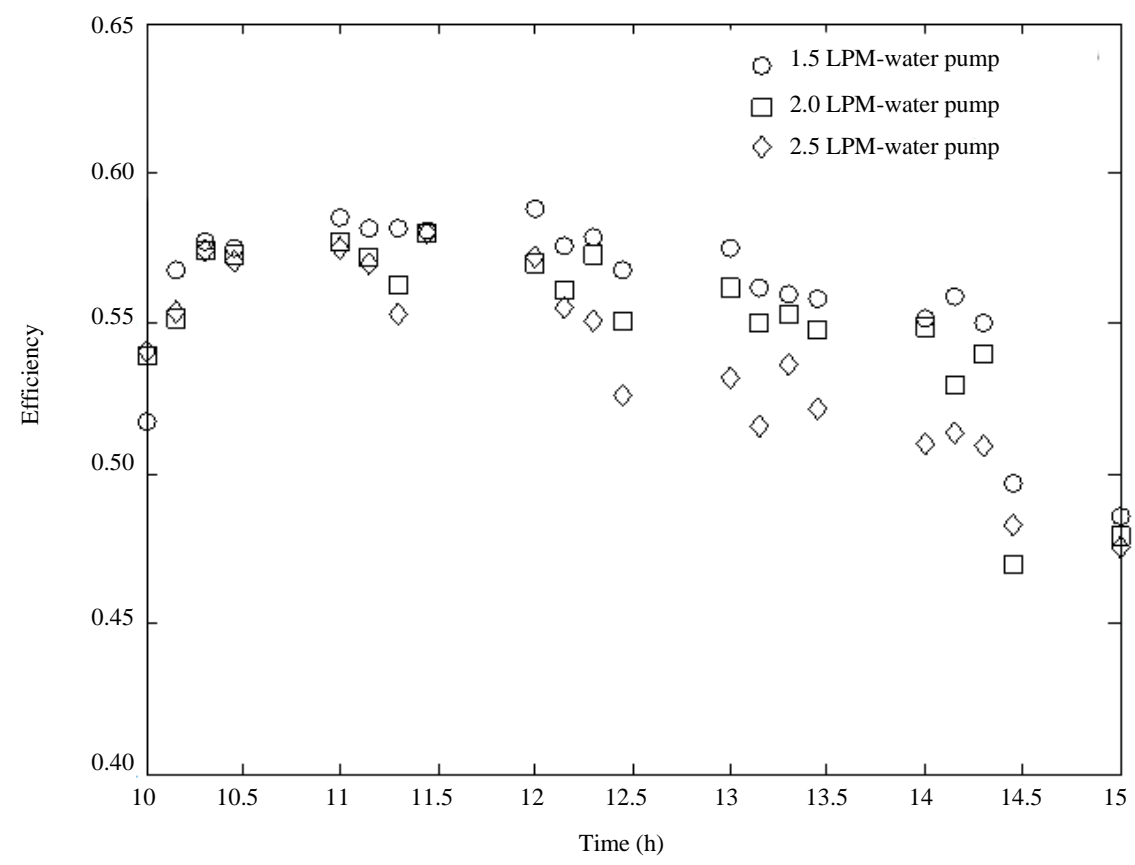

Fig. 3: Variation of efficiency with time for single-phase flow (water only) with different water flow rate

Table 2: Uncertainty of the instruments

\begin{tabular}{lll}
\hline Parameter & Unit & Comment \\
\hline Uncertainty of the temperature measurement and intensity of solar radiation & & \\
Solar collector inlet water temperature & ${ }^{\circ} \mathrm{C}$ & \pm 0.5 \\
solar collector outlet water temperature & ${ }^{\circ} \mathrm{C}$ & \pm 0.5 \\
solar collector surface temperature & ${ }^{\circ} \mathrm{C}$ & \pm 0.5 \\
Ambient temperature & ${ }^{\circ} \mathrm{C}$ & \pm 0.5 \\
intensity of solar radiation & $\mathrm{W} / \mathrm{m}^{2}$ & \pm 1.0 \\
Uncertainty of the volumetric flow rate measurements (L/min) & $\mathrm{L} / \mathrm{min}$ & \pm 0.25 \\
Water flow rate & $\mathrm{L} / \mathrm{min}$ & \pm 0.25 \\
Air flow rate & & \\
\hline
\end{tabular}




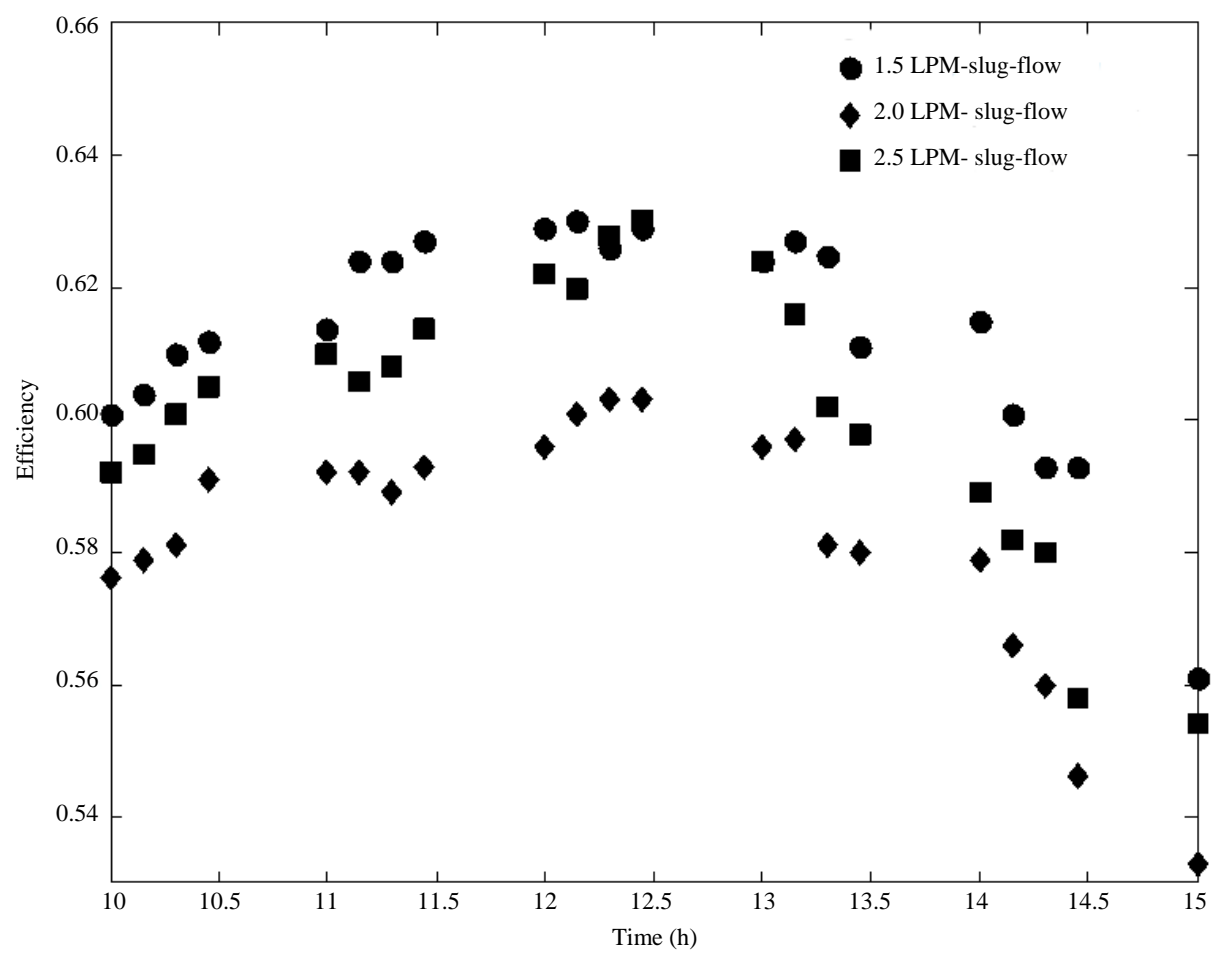

Fig. 4: Variation of efficiency with time for two-phase flow (air only) with different water flow rate

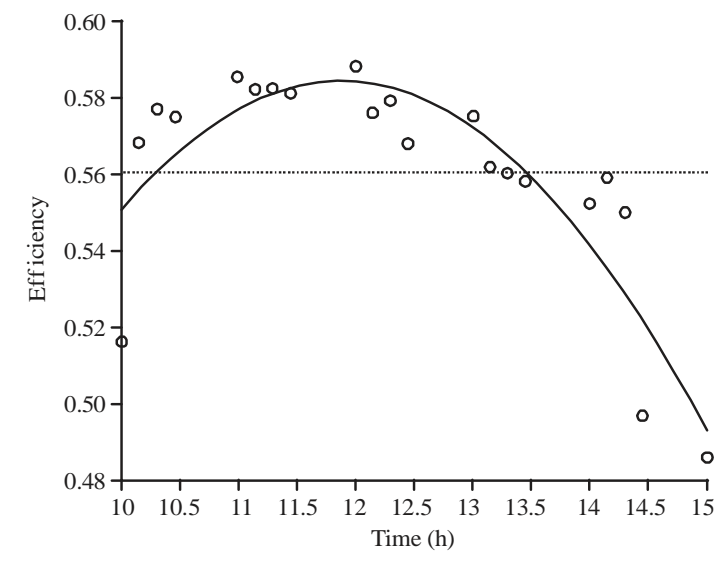

Fig. 5: Variation of efficiency with time for single phase flow (water only) 1.5 LPM

of the three different mass flow rate of water 1.5, 2.0 and 2.5 LPM was found to range between 47 and $58 \%$. The solar flat plate collector efficiency is higher for the smallest value of the water flow rate. As the mass flow rate increases the collector efficiency is decreases.

Figure 4 referred to the slug-flow study and the mass water flow is produced by injecting tiny air bubbles inside the risers tubes and collecting on the upper tube of solar collector. It's clearly shown that the variation of the solar flat plate efficiency of the three different mass flow rate of water 1.5, 2.0 and 2.5 LPM was found to range

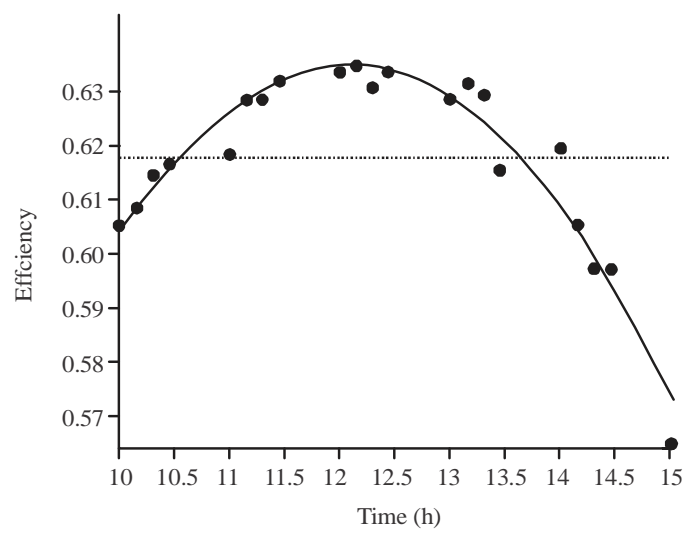

Fig. 6: Variation of efficiency with time for two phase flow (air only) 1.5 LPM

between 53 and 64\%. Also, as in Fig. 1 the solar flat plate collector efficiency is higher for the smallest value of water flow rate. Adding that, the mass flow rate increases the collector efficiency is decreases.

Figures 5 and 6 show the trend of solar flat plate collector efficiency with time for the first and second studies. Also, the mean value of collector efficiency was clearly shown for the first study is about $56.10 \%$ for 1.5 LPM and the slug-flow (bubbly pump) is about $61.35 \%$ also for 1.5 LPM. Figure 7 shows the trend of experimental friction factor with a volume flow rate for 


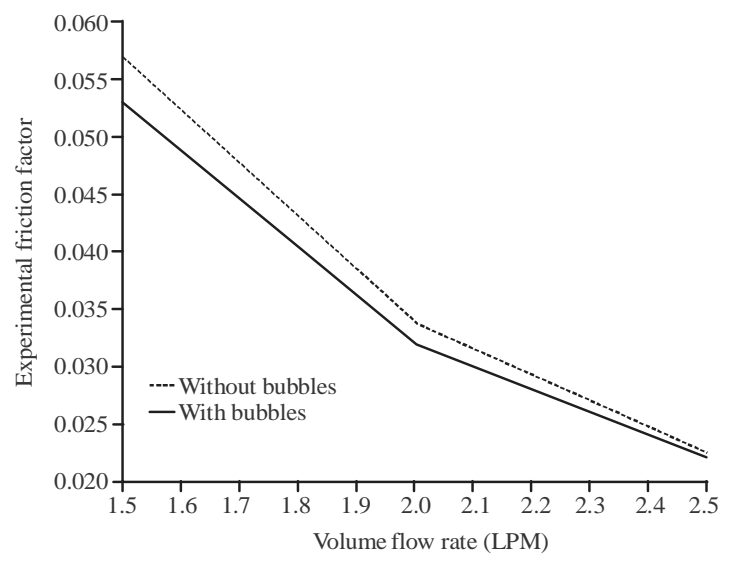

Fig. 7: Variation of experimental friction factor with volume flow rates for flow without and with bubbles effect

the first and second studies. It's clearly shown that the experimental friction factor for the second study is less than that for first study.

\section{CONCLUSION}

In this study, the tiny or micro-baubles air flow with different flow rates is injected inside the lower riser tubes and its effects on thermal characteristics including solar flat plate collector efficiency. It was observed that the thermal efficiency decreased with increases the effect of a micro-bubbles air injection at the lower riser tubes of solar flat plate collector. Also, the second study (slug-flow) findings showed that the average solar efficiency is more about $5 \%$ than the first study at the same water flow rate.

\section{REFERENCES}

Baqir, A.S., 2010. Theoretical and experimental study of direct-contact evaporation ofa volatile drops(n-pentane) in an immiscible liquid (distilled water). Ph.D. Thesis, Department Mechanical Engineering, University of Basrah, Basra, Iraq.

Baqir, A.S., H.B. Mahood, A.N. Campbell and A.J. Griffiths, 2016. Measuring the average volumetric heat transfer coefficient of a liquid-liquid-vapour direct contact heat exchanger. Applied Therm. Eng., 103: 47-55.

Bolaji, B.O., 2006. Flow design and collector performance of a natural circulation solar water heater. J. Eng. Applied Sci., 1: 7-13.
Ceylan, I., 2012. Energy and exergy analyses of a temperature controlled solar water heater. Energy Build., 47: 630-635.

Chong, K.K., K.G. Chay and K.H. Chin, 2012. Study of a solar water heater using stationary V-trough collector. Renewable Energy, 39: 207-215.

Ji, J., C. Luo, T.T. Chow, W. Sun and W. He, 2011. Thermal characteristics of a building-integrated dual-function solar collector in water heating mode with natural circulation. Energy, 36: 566-574.

Mahood, H.B., A.N. Campbell, A.S. Baqir, A.O. Sharif and R.B. Thorpe, 2018. Convective heat transfer measurements in a vapour-liquid-liquid three-phase direct contact heat exchanger. Heat and Mass Transfer, 54: 1697-1705.

Mahood, H.B., A.S. Baqir, A.D. Yousif, A.A. Khadom and A.N. Campbell, 2019. Direct contact evaporation of a single two-phase bubble in a flowing immiscible liquid medium Part I: Two-phase bubble size. Heat Mass Transfer, 55: 2593-2603.

Manjunath, M.S., V.K. Karanth and Y.N. Sharma, 2012. A comparative CFD study on solar dimple plate collector with flat plate collector to augment the thermal performance. World Acad. Sci. Eng. Technol., 2012: 969-975.

Matuska, T., V. Zmrhal and J. Metzger, 2009. Detailed modeling of solar flat-plate collectors with design tool kolektor 2.2. Proceedings of the 11th International IBPSA Conference, July 27-30, 2009, Glasgow, Scotland, pp: 2289-2296.

Sahoo, U., S.K. Singh, I. Barbate, R. Kumar and P.C. Pant, 2016. Experimental study of an inclined flat plate-type solar water distillation system. Renewable. Wind Water Solar, Vol. 3, No. 1. 10.1186/s40807-016-0026-4

Taherian, H., A. Rezania, S. Sadeghi and D.D. Ganji, 2011. Experimental validation of dynamic simulation of the flat plate collector in a closed thermosyphon solar water heater. Energy Convers. Manage., 52: 301-307.

Tang, R., Y. Cheng, M. Wu, Z. Li and Y. Yu, 2010. Experimental and modeling studies on thermosiphon domestic solar water heaters with flat-plate collectors at clear nights. Energy Convers. Manage., 51: 2548-2556.

Ullah, F., M.K. Khattak, M. Kang, N. Li, J. Yang and X. Wang, 2017. Numerical simulation on thermal performance of flat plate solar collector with double glass covers. J. Applied Sci., 17: 502-510. 